$E$

51

.1392

vol. 6

no. 1.

\title{
NMAIREF INDIAN NOTES
}

\section{AND MONOGRAPHS}

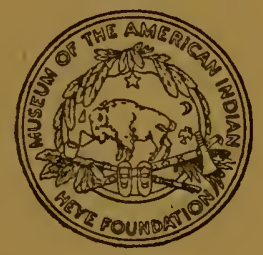

A SERIES OF PUBLICATIONS RELATING TO THE AMERICAN ABORIGINES

$$
\text { VOL. VI, No. } 1
$$

NEW YORK

MUSEUM OF THE AMERICAN INDIAN

HEYE FOUNDATION

1919 
Publications of the Museum of the American Indian, Heye Foundation

THE GEORGE G. HEYE EXPEDITION CONTRIBUTIONS TO SOUTH AMERICAN ARCHEOLOGY Vol. 1

The Antiquities of Manabi, Ecuador: A Preliminary Report. By Marshall H. Saville. I907. \$25.00.

Vol. 2

The Antiquities of Manabi, Ecuador: Final Report. By Marshall H. Saville. I9Io. $\$ 25.00$.

CONTRIBUTIONS FROM THE MUSEUM OF THE AMERICAN INDIAN, HEYE FOUNDATION

\section{Vol. 1}

No. I: Lucayan Artifacts from the Bahamas. By Theodoor de Booy. Reprinted from Amer. Anthropol., Vol. 15, 1913, No. I. 50c.

No. 2: Precolumbian Decoration of the Teeth in Ecuador, with some Account of the Occurrence of the Custom in other parts of North and South America. By Marshall H. Saville. Reprinted from Amer. Anthropol., Vol. I5, I9I3, No. 3. $50 c$.

No. 3: Certain Kitchen-middens in Jamaica. By Theodoor de Booy. Reprinted from Amer. Anthropol., Vol. 15, I9I3, No. 3. (Reprinted, 1919.) 50c.

No. 4: Porto Rican Elbow-stones in the Heye Museum, with discussion of similar objects elsewhere. By J. Walter Fewkes. Reprinted from Amer. Anthropol., Vol. 15, 19I3, No. 3. 50c. 


\title{
INDIAN NOTES \\ AND MONOGRAPHS
}



A SERIES OF PUBLICATIONS RELATING TO THE AMERICAN ABORIGINES

$$
\text { VOL. VI, No. } 1
$$

\author{
NEW YORK \\ MUSEUM OF THE AMERICAN INDIAN \\ HEYE FOUNDATION
}


This series of Indian Notes and Monographs is devoted primarily to the publication of the results of studies by members of the staff of the Museum of the American Indian, Heye Foundation, and is uniform with Hispanic Notes and Monographs, published by the Hispanic Society of America, with which organization this Museum is in cordial coöperation. 


\title{
BIBLIOGRAPHIC NOTES
}

\section{ON QUIRIGUA, GUATEMALA}

\author{
BY \\ MARSHALL H. SAVILLE
}





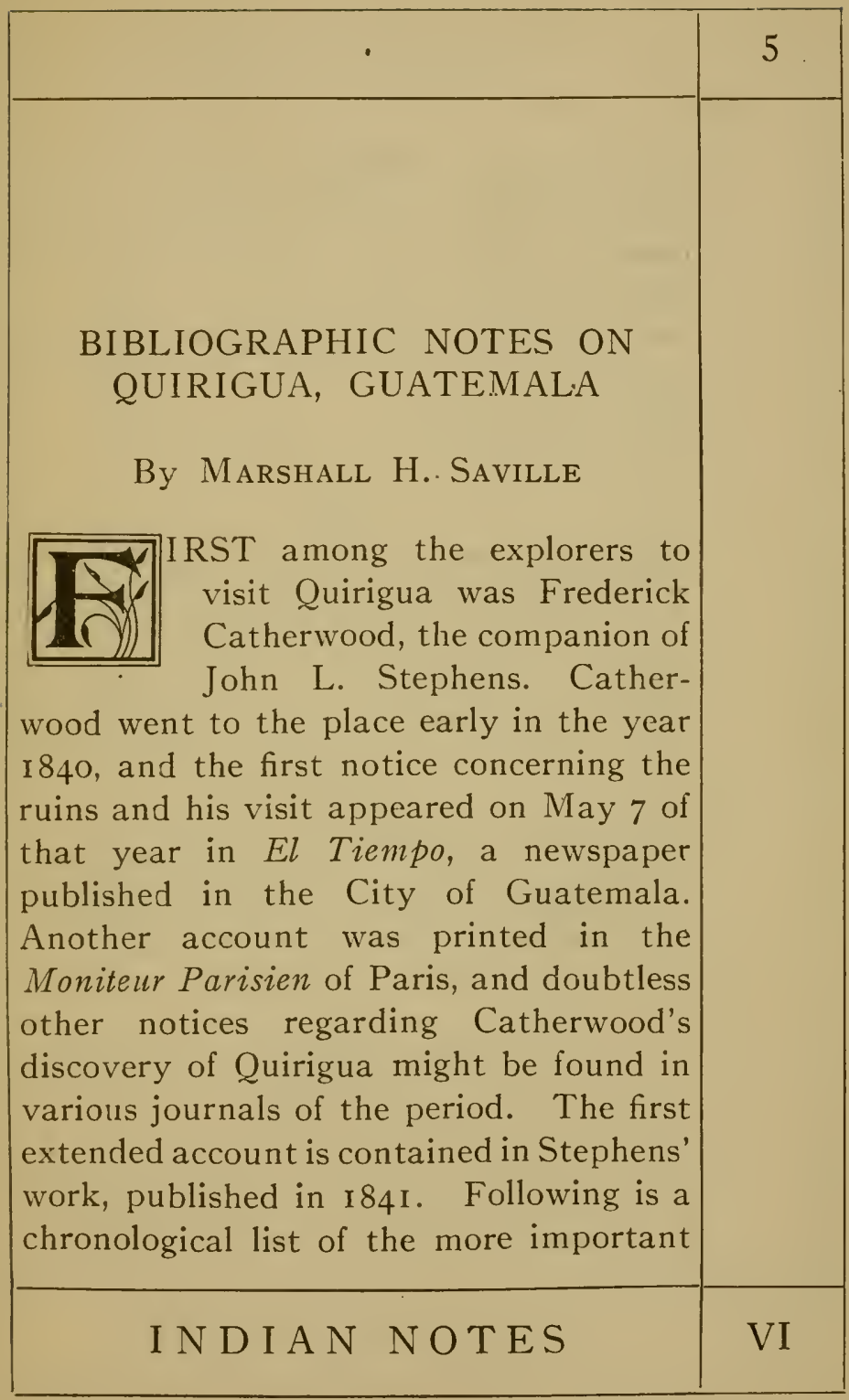




\begin{tabular}{|c|c|}
\hline 6 & Q U I R I G U A \\
\hline & $\begin{array}{l}\text { publications containing notices or de- } \\
\text { scriptions and views of Quirigua, but it } \\
\text { does not pretend to include all the writ- } \\
\text { ings devoted merely to the study or } \\
\text { mention of the hieroglyphic inscriptions, } \\
\text { nor those not containing original or } \\
\text { source material. } \\
\qquad 84 \text { I } \\
\text { STEPHENs, JoHN LLoyD. Incidents of } \\
\text { travel in Central America, Chiapas, } \\
\text { and Yucatan. New York. } \\
\text { For Quirigua see vol. II, pp. Ir8-I24, } 2 \text { pl. } \\
\text { AmériQuE CENTRALE. Colonisation du } \\
\text { district de Santo-Thomas, de Guate- } \\
\text { mala par la communauté de l'union. } \\
\text { fondée par la Compagnie Belge de } \\
\text { Colonisation. Collection de ren- } \\
\text { seignements publiés ou recuellis par. } \\
\text { la Compagnie. Paris. } \\
\text { Contains (pp. } 68-69 \text { ) Catherwood'saccount } \\
\text { Parisien, in the report of M. De Puydt. }\end{array}$ \\
\hline VI & I NDIAN NOTES \\
\hline
\end{tabular}




\begin{tabular}{|l|}
\hline B I B L I O G R A P H Y \\
I850 \\
BAILY, JoHN. Central America; de- \\
scribing each of the states of Guate- \\
mala, Honduras, Salvador, Nicara- \\
gua, and Costa Rica. London. \\
Contains (pp. 65-66) a brief account of \\
Quirigua. Baily, who was long a resident \\
of Guatemala, probably visited the ruins in \\
the forties, after Catherwood's notice was \\
printed in El Tiempo. It appears that Baily \\
lived for some time in Izabal, and made \\
drawings of many of the sculptures. Bras- \\
seur de Bourbourg, in his work on Palenque, \\
published in I866, stated that he visited \\
Quirigua in I863, and secured the Baily \\
drawings; but this is a misstatement, as in \\
I875 Dr Berendt found them in possession \\
of Don Francisco Gavarrete, of Guatemala, \\
and made copies of at least a portion of them. \\
Dr Valentini made tracings of three of \\
Berendt's copies, which are now in the library \\
of the present writer. They are exceedingly \\
defective and inexact. \\
STEPHENS, JoHN LLoyD, and CATHER- \\
wooD, FREDERICK. Incidents of \\
travel in Central America, Chiapas, \\
and Yucatan. Revised from the \\
A N D M O N O G R A P H S
\end{tabular}




\begin{tabular}{|c|c|}
\hline 8 & Q U I R I G UA \\
\hline & $\begin{array}{l}\text { latest American edition with addi- } \\
\text { tions by Frederick Catherwood. } \\
\text { London. } \\
\text { The original edition of two volumes has } \\
\text { been brought into the compass of a single } \\
\text { volume. The account of Quirigua is on } \\
\text { pp. 29I-297, the two plates being pp. } 292 \\
\text { and 294. There is only a single change in } \\
\text { the reading in the two editions. Stephens, } \\
\text { in closing his account, says, in tegard to } \\
\text { negotiations he entered into for the purchase } \\
\text { of the monuments for removal to the United } \\
\text { States, that he "left an offer with Mr } \\
\text { Savage, the result of which is uncertain; } \\
\text { but I trust that when these pages reach the } \\
\text { hands of the reader, two of the largest } \\
\text { monuments will be on their way to this city" } \\
\text { (New York). In the London edition of } \\
\text { I } 854 \text { this paragraph reads, "I left an offer } \\
\text { with Mr Savage, which was not accepted, } \\
\text { and the monuments remain where first dis- } \\
\text { covered." } \\
\text { SCHERzER, KARL. Ein Besuch bei den } \\
\text { Ruinen von Quiriguá im Staate } \\
\text { Guatemala in Central - Amerika. } \\
\text { Kais. Akademie der Wissenschaften, } \\
\text { IVien, Bd. XVI, pp. } 22 S-240 \text {. Also } \\
\text { reprint, I } 5 \text { pp. }\end{array}$ \\
\hline VI & I NDIAN NOTES \\
\hline
\end{tabular}




\section{B I B L I O G R A P H Y}

Scherzer was at Quirigua in 1854 , and his account of the ruins is important.

\section{878}

Habel, S. The sculptures of Santa Lucia Cosumalwhuapa in Guatemala, with an account of travels in Central America and on the western coast of South America. Smithsonian Contributions to Knowledge, no. 269, Washington.

Habel gives a brief description (pp. I4-16) of some of the sculptures; he was there early in the sixties, as he spent seven years in Central America and South America, from I 862 to I 869 .

\section{2}

Bancroft, Hubert Howe. The works of Hubert Howe Bancroft, Vol. IV. The Native Races, vol. Iv, Antiquities. San Francisco.

A resumé (pp. Io8-1r5) made before Maudslay's researches, and based largely on the works of Stephens, Catherwood, and Scherzer. 


\begin{tabular}{|c|c|}
\hline 10 & Q U I R I G U A \\
\hline & 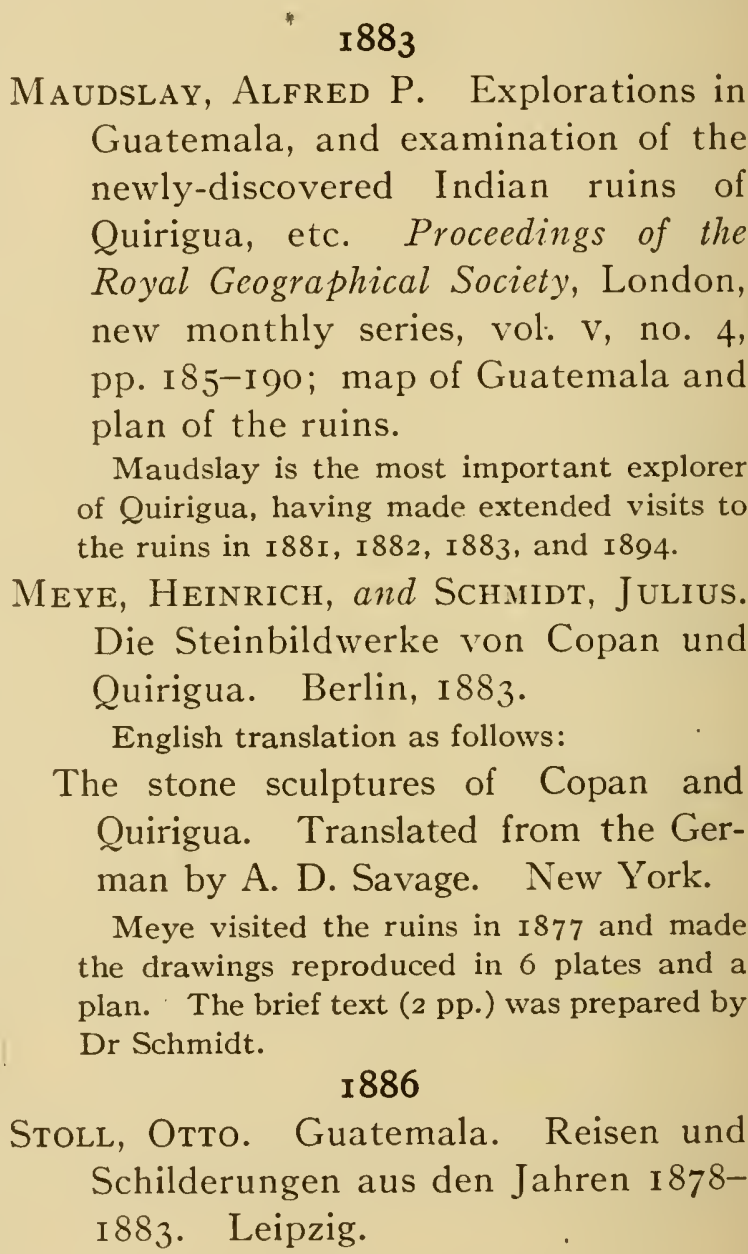 \\
\hline VI & I NDIAN NOTES \\
\hline
\end{tabular}




\section{B I B L I O G R A P H Y}

See pp. 443-453. The author visited Quirigua in 1882 .

\section{887}

Brigham, William T. Guatemala the land of the quetzal. New York.

Brigham was at Quirigua in 1883 . His account (pp. $215^{-223}$ ) is illustrated with 3 pl., 2 fig., and a plan of the ruins.

\section{888}

Eisen, Gustav. On some ancient sculptures from the Pacific coast of Guatemala. Memoirs of the California Academy of Sciences, San Francisco, vol. II, no. 2.

Contains no account of the ruins, but Eisen states that he was at Quirigua in I882. He prepared a report on the ruins for publication by the Smithsonian Institution, but a portion of his manuscript was lost, and as Maudslay meanwhile had presented his report to the Royal Geographical Society, Eisen did not deem it necessary to write another.

\section{I892}

Saville, Marshall H. Vandalism among the antiquities of Yucatan 


\begin{tabular}{|c|c|}
\hline 12 & Q U I R I G U A \\
\hline & 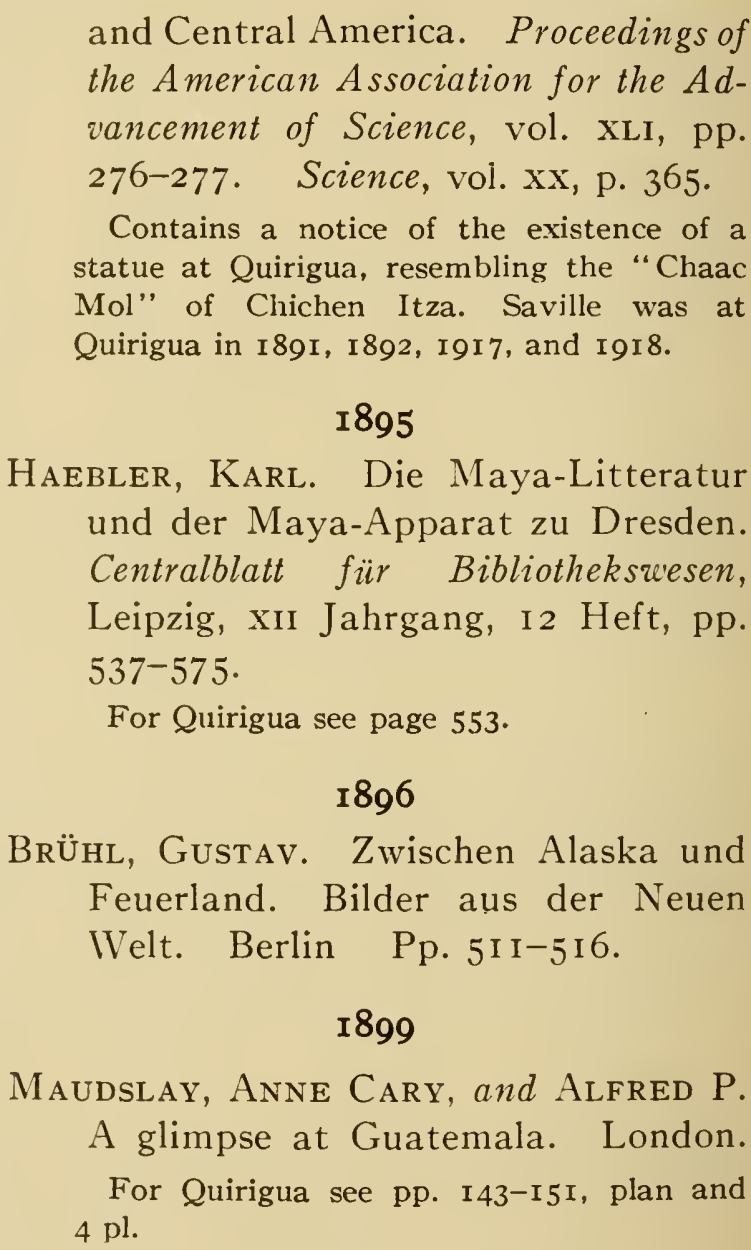 \\
\hline VI & I NDIAN NOTES \\
\hline
\end{tabular}




\section{B I B L I O G R A P H Y}

Alford, W. V. Fragments from prehistoric America. The wonderful ruins of Quirigua in Central America. Home Magazine, New York, Feb., pp. I 43-I 48, 5 ills.

Seler, Eduard. Die Monumente von Copan und Quiriguá und die Altarplatten von Palenque. Verhandlungen der Berliner Anthropologischen Gesellschaft, Zeitschrift für Ethnologie, Bd. xxxi, pp. 670-738, 227 fig.

This essay has been pubiished as article 21 of Seler's Gesammelte Abhandlungen zur Amerikanischen Sprach- und Alterthumskunde, Berlin, Bd. I, 1902.

\section{9-1902}

Maudslay, Alfred P. Biologia Centrali-Americana; or contributions to the knowledge of the fauna and flora of Mexico and Central America. Edited by F. Ducane Godman and Osbert Salvin. Archeology, by Maudslay. London, I899-I902. Vol. II, text, pp. I-I9, 9 fig.; vol. II, plates, nos. i-lxvi.

\section{A N D M NOGRAPHS}




\begin{tabular}{|c|c|}
\hline 14 & Q U I R I G UA \\
\hline & $\begin{array}{l}\text { This magnificent work, containing a plan, } \\
\text { photographs, and drawings of all the then } \\
\text { known monuments of Quirigua above ground, } \\
\text { is final so far as it is necessary for us to have } \\
\text { material for a study of the great monuments } \\
\text { of this ruined Mayan city. What is now } \\
\text { all-important is a systematic excavation of } \\
\text { the site. The present writer has been told } \\
\text { that when the ruins were surveyed by a party } \\
\text { of engineers for the Guatemala government } \\
\text { in I894, a building was discovered about } \\
\text { one mile south of the main group. On the } \\
\text { front wall of a partly destroyed edifice, it is } \\
\text { said, there is represented in carved stones } \\
\text { the transportation of a monolith. It is } \\
\text { tied to long poles, and carried by I32 men, } \\
\text { each man bearing the weight by means of } \\
\text { the mecapilli, or headstrap. This report is } \\
\text { said to be deposited in the Government } \\
\text { archives in Guatemala City. } \\
\text { SELER, EDUARD. Einiges mehr über die } \\
\text { Monumente von Copan und Qui- } \\
\text { riguá. Verhandlungen der Berliner } \\
\text { Anthropologischen Gesellschaft, Zeit- } \\
\text { schrift für Ethnologie, Bd. XxxII, pp. } \\
\text { I } 88-227,202 \text { fig. } \\
\text { as article } 22 \text { of his Gesammelte Abhandlungen }\end{array}$ \\
\hline VI & I NDIAN NOTES \\
\hline
\end{tabular}




\section{B I B L I O G R A P H Y}

zur Amerikanischen Sprach- und Alterthumskunde, Berlin, Bd. I, I902.

Seler, Cecilie. Auf alten Wegen in Mexiko und Guatemala. Reiseerinnerungen und Eindrücke aus der Jahren I 895-I897. Berlin. Pp. 327-330, 7 ills.

Dr and Mrs Seler were at Quirigua in January, I 897.

\section{I904}

Thomas, Cyrus. Mayan calendar systems. I. Twenty-second Annual Report of the Bureau of American Ethnology, Washington.

Pages 203-233 treat of the interpretation of the hieroglyphic inscriptions of the stelæ of Quirigua.

\section{I909}

Winter, Nevin O. Guatemala and her people of today. Boston.

Winter visited the ruins, which are now easily reached by railroad, but his account (pp. $155-164$ ) is taken from an article by Saville published in the New York Herald of Oct. I6, I898, entitled "Ruins of a vanished race found in a Guatemala valley," I p., 7 ills.

\section{A N D M ONOGRAPHS}




\begin{tabular}{|c|c|}
\hline 16 & Q U I R I G U A \\
\hline & 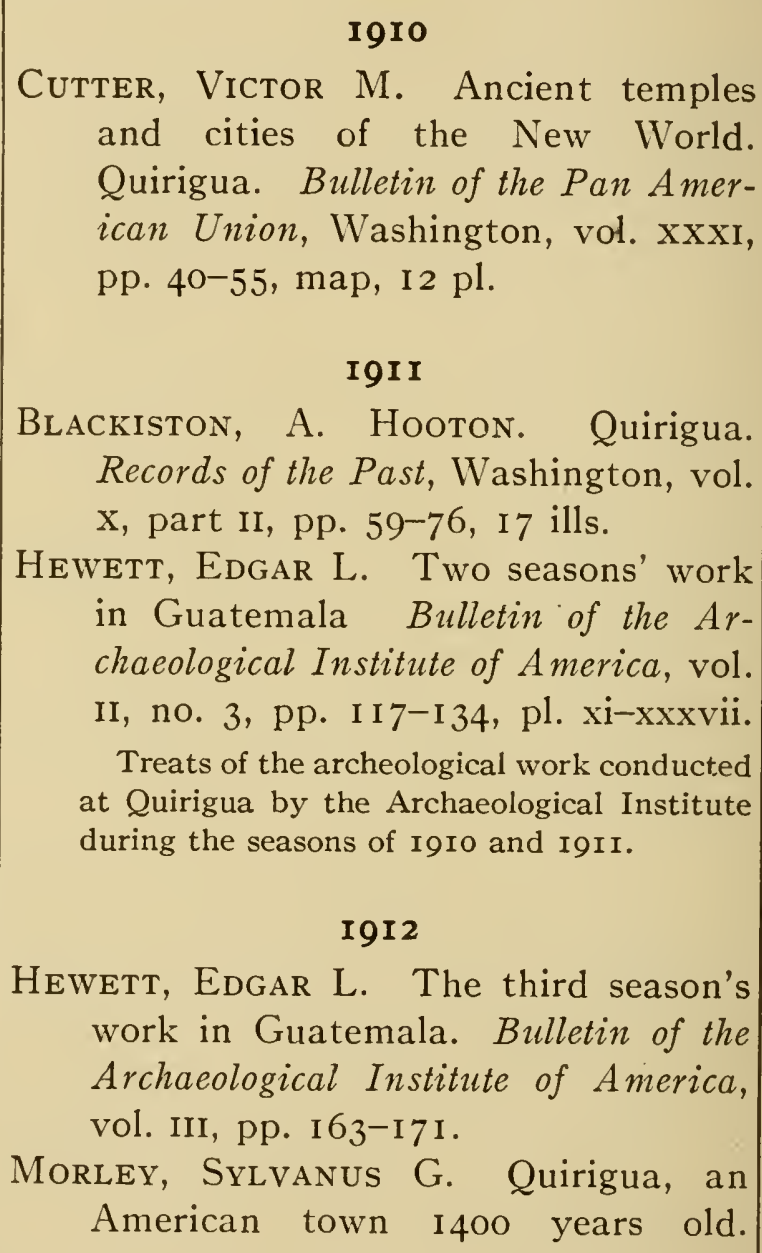 \\
\hline VI & I NDIAN NOTES \\
\hline
\end{tabular}




\section{B I B L I O G R A P H Y}

Scientific American, New York, vol. cvir, no. 5, p. 96.

\section{I9I3}

Morley, Sylvanus G. Excavations at Quirigua, Guatemala. National Geographic Magazine, Washington, vol. xxIv, no. 3, pp. 339-36I, 23 figs., 2 plans.

Hewett, Edgar L. The excavation of Quirigua, Guatemala, by the School of American Archaeology. Proceedings of the Eighteenth International Congress of Americanists, IgI 2, London, pp. 24I-248, 3 pl., 6 figs.

Gordon, George B. An unpublished inscription from Quirigua, Guatemala. Proceedings of the Eighteenth International Congress of Americanists, I9I2, London, pp. 238-240, 2 pl., 2 figs.

Spinden, Herbert J. A study of Maya art, its subject matter and historical development. Memoirs of the Peabody Museum of American Archaeol-

A N D MONOGRAPHS 


\begin{tabular}{|c|c|}
\hline 18 & Q U I R I G U A \\
\hline & $\begin{array}{l}\text { ogy and Ethnology, vol. vI, Cam- } \\
\text { bridge. } \\
\text { Treats of the art of Quirigua on various } \\
\text { pages, and of the chronological development } \\
\text { of the sculptures on pp. I 73-177. } \\
\text { I9I4 } \\
\text { MoRLEY, SyLVANUS G. Archaeological } \\
\text { research at the ruins of Chichen } \\
\text { Itza, Yucatan. Extracted from Re- } \\
\text { ports upon the Present Condition } \\
\text { and Future Needs of the Science of } \\
\text { Anthropology, published by the Car- } \\
\text { negie Institution of Washington, pp. } \\
\text { 6I-9I. } \\
\text { Mentions Quirigua briefly, and has a short } \\
\text { list of titles. } \\
\text { Prehistoric Quirigua the unfinished } \\
\text { city. El Palacio, Santa Fe, New } \\
\text { Mexico, vol. I, no. 3, pp. I-3, } 2 \text { ills. } \\
\text { HEwETT, EDGAR L. New stela is found } \\
\text { in Montagua [Motagua] valley. El } \\
\text { Palacio, Santa Fe, New Mexico, vol. } \\
\text { I, nos. 4-5, p. I, } 3 \text { ills. } \\
\text { [WALTER, PAUL A. F.] City built upon } \\
\text { city by prehistoric Mayas. El Pa- }\end{array}$ \\
\hline VI & INDIAN NOTES \\
\hline
\end{tabular}




\section{B I B L I O G R A P H Y}

lacio, Santa Fe, New Mexico, vol. II, no. I, p. I, 3 ills.

\section{I9I5}

Morley, Sylvanus G. An introduction to the study of the Maya hieroglyphs. Bulletin 57, Bureau of American Ethnology, Washington.

Interpretation of the hieroglyphic inscriptions at Quirigua, passim.

JUDD, NEIL M. The use of glue molds in reproducing aboriginal monuments at Quirigua, Guatemala. American Anthropologist, n. s., Lancaster, Pa., vol. Xvil, no. I, pp. I28-I 38 , pl. xii-xiii, figs. 29-34.

Hewett, Edgar L. Ancient America at the Panama-California Exposition. Art and Archaeology, Washington, vol. II, no. 3 , pp. 64-I0.2.

Speaks of the work of the School of American Archaeology at Quirigua and of the reproductions made of many of the monuments for exhibition at the Exposition.

\section{A ND MONOGRAPHS}




\begin{tabular}{|c|c|}
\hline 20 & Q U I R I G UA \\
\hline &  \\
\hline VI & I NDIAN NOTES \\
\hline
\end{tabular}




\section{B I B L I O G R A P H Y}

- A Quirigua mystery. Art and Archaeology, Washington, vol. IV, no. 6, p. 34I, pl.

The plate illustrates in color a vase recovered from the ruins.

Lummis, Charles F. Where the stones come to life. Art and Archaeology, Washington, vol. Iv, no. 6, pp. 28I290, 6 ills.

An account by a member of the Quirigua expedition of the Archaeological Institute in I9I3.

\section{I9I7}

Holmes, William H. The great dragon of Quirigua. Smithsonian Report for I9I5, Washington, pp. 447-460, 10 pl.

This article is a revision of the author's paper of I9I6.

Morley, Sylvanus G. The hotun as the principal chronological unit of the old Maya empire. Proceedings of the Nineteenth International Congress of Americanists, I9I5, Washington, I9I7, pp. I95-20I, $5 \mathrm{pl}$.

\section{A N D MONOGRAPHS}




\begin{tabular}{|c|c|}
\hline 22 & Q U I R I G U A \\
\hline & $\begin{array}{l}\text { The author shows that the stelae at } \\
\text { Quirigua and at other Mayan sites were } \\
\text { erected at intervals of five years. Gives a } \\
\text { map of the site. } \\
\text { The rise and fall of the Maya } \\
\text { civilization in the light of the monu- } \\
\text { ments and the native chronicles. } \\
\text { Proceedings of the Nineteenth Inter- } \\
\text { national Congress of Americanists, } \\
\text { I9I5, Washington, pp. I } 40-149 \text {, I I pl. } \\
\text { Plate v gives a painting of the Quirigua } \\
\text { site, and on p. I43 Morley suggests that } \\
\text { Quirigua flourished toward the close of the } \\
\text { so-called Middle Period of Maya civilization, } \\
\text { being probably a colony from Copan estab- } \\
\text { lished about the year } 450 \text { A.D. } \\
\text { SpINDEN, HERBERT J. Recent progress } \\
\text { in the study of Maya art. Proceed- } \\
\text { ings of the Nineteenth International } \\
\text { Congress of Americanists, I9I5, Wash- } \\
\text { ington, pp. I } 65 \text {-I } 77,2 \text { pl., I } 3 \text { fig. } \\
\text { A study of the age of Quirigua is included, } \\
\text { based on the chronological sequence of } \\
\text { Mayan sculptures as first demonstrated by } \\
\text { the author in I9og. }\end{array}$ \\
\hline VI & I NDIAN NOTES \\
\hline
\end{tabular}


. 

No. 5: Note on the Archeology of Chiriqui. By George Grant MacCurdy. Reprinted from Amer. Anthropol., Vol. I5, I9I3, No. 4. $50 c$.

No. 6: Petroglyphs of Saint Vincent, British West Indies. By Thomas Huckerby. Reprinted from Amer. Anthropol., Vol. 16, 19I4. No. 2. 50c.

No. 7: Prehistoric Objects from a Shell-heap at Erin Bay, Trinidad. By J. Walter Fewkes. Reprinted from Amer. Anthropol., Vol. I6, I9I4, No. 2. $50 \mathrm{c}$.

No. 8: Relations of Aboriginal Culture and Environment in the Lesser Antilles. By J. Walter Fewkes. Reprinted from Bull. Amer. Geogr. Soc., Vol. 46, I914, No. 9. 50c.

No. 9: Pottery from Certain Caves in Eastern Santo Domingo, West Indies. By Theodoor de Booy. Reprinted from Amer. $A n$ thropol., Vol. I7, I9I5, No. I. 50c.

\section{Vol. 2}

No. I: Exploration of a Munsee Cemetery near Montague, New Jersey. By George G. Heye and George H. Pepper. 1915. \$1.00.

No. 2: Engraved Celts from the Antilles. By J. Walter Fewkes. 19I5. 50c.

No. 3: Certain West Indian Superstitions Pertaining to Celts. By Theodoor de Booy. Reprinted from Journ. Amer. Folk-Lore, Vol. 28, No. 107, I9I5. $50 \mathrm{C}$.

No. 4: The Nanticoke Community of Delaware. By Frank G. Speck. I9I5. \$1.00.

No. 5: Notes on the Archeology of Margarita Island, Venezuela. By Theodoor de Booy. I9I6. 50c.

No. 6: Monolithic Axes and Their Distribution in Ancient America. By Marshall H. Saville. 1916. 50c. 


\section{0}

Vol. 3

Physical Anthropology of the Lenape or Delawvares, and of the Eastern Indians in General. By Aleš Hrdlička. (Bur. of Amer. Ethnol., Bull. 62, 1916, with added title-page and cover.) \$I.00.

\section{Vol. 4}

No. I: The Technique of Porcupine-Quill Decoration among the North American Indians. By William C. Orchard. I9I6. \$1.00.

No. 2: Certain Archeological Investigations in Trinidad, British West Indies. By Theodoor de Booy. Reprinted from Amer. Anthropol., Vol. 19, I917, No. 4. 50c.

No. 3: The Nacoochee Mound in Georgia. By George G.5Heye, F. W. Hodge, and George H. Pepper. I9I8. \$1.50.

\section{Vol. 5}

No. I: A Letter of Pedro de Alvarado Relating to His Expedition to Ecuador [I534]. By Marshall H. Saville. I9I7. 50c.

No. 2: The Diegueño Ceremony of the DeathImages. By E. H. Davis. I919. 50c. No. 3: Certain Mounds in Haywood County, North Carolina. By George G. Heye. Reprinted from Holmes Anniversary Volume, I9I6. I9I9. 50c.

No. 4: Exploration of Aboriginal Sites at Throgs Neck and Clasons Point, New York City. By Alanson Skinner. I9I9. \$1.00. Address:

Museum of the American Indian, Heye FOUNDATION, BROADWAY AT I55TH ST., NEW YORK City. 